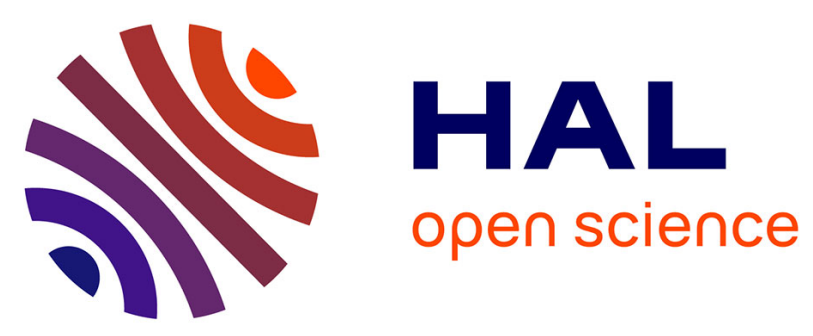

\title{
Characterisation of the mycelial glycoproteins of the 'Ascochyta pea complex' (Ascochyta pisi Lib., Mycosphaerella pinodes (Berk. and Blox.) and Phoma medicaginis var. pinodella (Jones) Boerema)
}

Edouard Mendes-Pereira, Samar Faris-Mokaiesh, Jean Bertrandy, Didier Spire

\section{- To cite this version:}

Edouard Mendes-Pereira, Samar Faris-Mokaiesh, Jean Bertrandy, Didier Spire. Characterisation of the mycelial glycoproteins of the 'Ascochyta pea complex' (Ascochyta pisi Lib., Mycosphaerella pinodes (Berk. and Blox.) and Phoma medicaginis var. pinodella (Jones) Boerema). Agronomie, 1999, 19 (1), pp.21-29. hal-00885910

\section{HAL Id: hal-00885910 https://hal.science/hal-00885910}

Submitted on 1 Jan 1999

HAL is a multi-disciplinary open access archive for the deposit and dissemination of scientific research documents, whether they are published or not. The documents may come from teaching and research institutions in France or abroad, or from public or private research centers.
L'archive ouverte pluridisciplinaire HAL, est destinée au dépôt et à la diffusion de documents scientifiques de niveau recherche, publiés ou non, émanant des établissements d'enseignement et de recherche français ou étrangers, des laboratoires publics ou privés. 


\title{
Characterisation of the mycelial glycoproteins of the 'Ascochyta pea complex' (Ascochyta pisi Lib., Mycosphaerella pinodes (Berk. and Blox.) and Phoma medicaginis var. pinodella (Jones) Boerema)
}

\author{
Édouard Mendes-Pereira*, Samar Faris-Mokaiesh, Jean Bertrandy, Didier Spire \\ Unité de phytopathologie, Inra, route de Saint-Cyr, 78026 Versailles, France
}

(Received 20 December 1997; accepted 24 November 1998)

\begin{abstract}
Mycelial glycoproteins of the three phytopathogenic fungi causing Ascochyta blight on pea (Ascochyta pisi, Mycosphaerella pinodes (anamorph Ascochyta pinodes) and Phoma medicaginis var. pinodella) were investigated using affinity chromatography. Three types of functional structures were present in the three pathogens, $\mathrm{N}$-glycosylated mannose structures, $\alpha$-D-glucosyl residues and terminal $\alpha$-D-galactosamine residues. The antigenic properties of the different glycoprotein fractions extracted from the three species were tested by ACP-ELISA using an antiserum produced against Mycosphaerella pinodes soluble mycelial extract. For all three fungi, the fraction containing a high mannose structure was preferentially recognised, whereas the fraction with glycosyl residues showed a weak reaction. The fraction containing $\alpha$-D-galactosamine residues was not recognised. The most antigenic (mannose-rich) glycoprotein fraction of Mycosphaerella pinodes was used as immunogen to produce a polyclonal antiserum, in order to evaluate its specificity. The response (by ACP-ELISA) to this serum is similar for the three fungi. (C Inra/Elsevier, Paris.)
\end{abstract}

Pisum sativum / pea / Ascochyta / functional glycoprotein / mannose structure / affinity

Résumé - Caractérisation des glycoprotéines mycéliennes des Ascochyta du pois (Ascochyta pisi Lib., Mycosphaerella pinodes (Berk. et Blox.) et Phoma medicaginis var. pinodella (Jones) Boerema ). Les glycoprotéines du mycélium de trois champignons phytopathogènes apparentés responsables de l'anthracnose du pois (Ascochyta pisi, Mycosphaerella pinodes (anamorphe Ascochyta pinodes) et Phoma medicaginis var. pinodella) ont été étudiées. La nature de ces glycoprotéines fonctionnelles a été déterminée en se basant sur leur affinité pour différentes lectines. Trois types de structures ont pu être mises en évidence chez les trois agents pathogènes, des structures $\mathrm{N}$-glycosylées riches en mannose, des résidus $\alpha$-D-glucosyle, et des résidus $\alpha$-D-galactosamine terminaux. Les propriétés antigéniques des dif-

Communicated by Jan Stenlid (Uppsala, Sweden)

* Correspondence and reprints

E-mail: pereira@versailles.inra.fr 
férentes fractions glycoprotéiques des trois parasites ont été comparées par une méthode immunoenzymatique (ACPElisa) à l'aide d'un sérum dirigé contre les extraits mycéliens solubles de Mycosphaerella pinodes. Pour chacune des trois espèces étudiées, une forte réaction est observée pour la fraction glycoprotéique riche en mannose, tandis que celle de la fraction présentant des résidus glucosyle est plus faible. La réponse de la fraction caractérisée par des résidus $\alpha$-D-galactosamine terminaux n'est pas significativement différente de celle du témoin. La fraction glycoprotéique de Mycosphaerella pinodes la plus antigénique (riche en mannose) a été utilisée pour produire un sérum polyclonal, dans le but d'évaluer sa spécificité. La réponse (en Elisa indirect) vis-à-vis de ce sérum est similaire pour les trois champignons. (C Inra/Elsevier, Paris.)

Pisum sativum / pois / Ascochyta / glycoprotéine fonctionnelle / structure mannose / affinité

\section{INTRODUCTION}

Three related fungi, namely Ascochyta pisi Lib., Mycosphaerella pinodes (Berk. and Blox.) (anamorph Ascochyta pinodes) and Phoma medicaginis var. pinodella (Jones) Boerema, can cause important yield losses in the pea (Pisum sativum) crop. Infected seeds are often symptomless. The sexual form is only known for Mycosphaerella pinodes, which is also considered to be the most damaging of the three [24].

Their identification on the basis of symptoms or morphological criteria is lengthy because sporulation is needed. Neither soluble mycelial protein electrophoresis nor serology could differentiate the three pathogens clearly $[3,10]$. Only recently biochemical and molecular tools have given promising results [9].

Several authors suggest that glycoprotein antigens can improve serological diagnostic tests $[1,2$, 18, 29]. Wycoff and Ayers [27] have shown that monoclonal antibodies raised against Phytophthora megasperma antigens recognise carbohydrate epitops.

The importance of pathogen glycoproteins in host-pathogen interaction (especially at the adhesion and recognition levels) has been shown [5, 7 , 12, 14, 15, 17, 19, 22]. Chrispeels and Raikhel [6] proposed that the carbohydrate binding domains of plant vacuolar lectins have become incorporated into families of proteins that play important roles in different plant defence mechanisms, as the chitin binding domain found in several proteins inhibitory to fungi. Wade and Albersheim [26] isolated, from culture filtrates of a non-virulent race of Phytophthora megasperma, a glycoprotein capable of protecting the host (soybean) from the attack of a virulent race.

In this study different lectins were used to determine and compare the functional glycan containing structures of the three pea pathogens. The objectives of this research work were: i) the characterisation of the mycelial glycosylated proteins of the three related pathogens by affinity chromatography using different plant lectins; ii) the comparison of their different mycelial glycosylated fractions, particularly their antigenic properties by antigen-coated plate ELISA; iii) the determination of the specificity of a polyclonal serum raised against the most antigenic fraction of Mycosphaerella pinodes.

\section{MATERIAL AND METHODS}

\subsection{Fungal cultures}

The following fungal isolates were used: Ascochyta pisi (Ap-001 Fra), Mycosphaerella pinodes (Mp-001Fra) and Phoma medicaginis var. pinodella (Pmp-001Fra). Faris-Mokaiesh et al. [9] described previously the origin and culture of fungal isolates.

\subsection{Methods}

\subsubsection{Extraction of soluble mycelial proteins}

A sample $(100 \mathrm{mg})$ of freeze-dried mycelium was ground in liquid nitrogen using a mortar and pestle, and 
suspended in $1.0 \mathrm{~mL}$ of extraction buffer (PBS - phosphate buffered saline: $8 \mathrm{~g} \mathrm{NaCl}, 0.2 \mathrm{~g} \mathrm{KCl}$, $0.2 \mathrm{~g} \mathrm{KH}_{2} \mathrm{PO}_{4}, 2.9 \mathrm{~g} \mathrm{Na}_{2} \mathrm{HPO}_{4}, 12 \mathrm{H}_{2} \mathrm{O}, \mathrm{H}_{2} \mathrm{O}$ q.s.q. $1000 \mathrm{~mL}, 2 \mathrm{mM}$ EDTA, $10^{-4} \mathrm{mM}$ pepstatine $\mathrm{A}$ and 1 $\mathrm{mM}$ phenyl methyl sulfonyl fluoride (PMSF), $\mathrm{pH}$ 7.4). Suspensions were chilled in an ice bath for $1-3 \mathrm{~h}$ and centrifuged at $20000 \mathrm{~g}$ for $30 \mathrm{~min}$ at $4{ }^{\circ} \mathrm{C}$. The supernatant was then collected, divided into $100 \mu \mathrm{L}$ aliquots and stored at $-80^{\circ} \mathrm{C}$ for later use [10].

\subsubsection{Extraction of lithium chloride soluble glycoproteins}

Several authors $[16,23,26]$ have shown that cell wall glycoproteins from different micro-organisms can be extracted with lithium chloride.

A sample $(1 \mathrm{~g})$ of freeze-dried mycelium was ground in liquid nitrogen with a mortar and pestle, suspended for $30 \mathrm{~min}$ in $10 \mathrm{~mL}$ of a solution containing $1 \mathrm{M}$ lithium chloride, $20 \mathrm{mM}$ sodium phosphate, $\mathrm{pH} 7$, and $0.1 \mathrm{M}$ PMSF, and centrifuged at $20000 \mathrm{~g}$ for $20 \mathrm{~min}$ at $4{ }^{\circ} \mathrm{C}$. The supernatant was then collected, dialysed against a solution containing $20 \mathrm{mM}$ Tris $\mathrm{HCl}, \mathrm{pH} 7.4,0.5 \mathrm{M}$ $\mathrm{NaCl}, 1 \mathrm{mM} \mathrm{MgCl}, 1 \mathrm{mM} \mathrm{MnCl}, 1 \mathrm{mM} \mathrm{CaCl}$, filtered successively on a Whatman GF/B $1.0 \mu \mathrm{m}$ and a MillexHV Millipore $0.45 \mu \mathrm{m}$ filters, and desalted on a column of Sephadex G25 (PD 10, Pharmacia).

\subsubsection{Extraction of lithium chloride insoluble glycoproteins}

Sodium deoxycholate was used in order to extract the glycoproteins that were not extracted by lithium chloride. The insoluble fraction was ground in liquid nitrogen with a mortar and pestle, and suspended for $30 \mathrm{~min}$ in $1 \mathrm{~mL}$ of a solution of Tris/ $\mathrm{HCl}-0.1 \mathrm{M}$ Tris, $\mathrm{pH} 8.0$, containing $7 \%$ sodium deoxycholate. The supernatant was then collected, dialysed against a solution containing $20 \mathrm{mM}$ Tris $\mathrm{HCl} \mathrm{pH} 7.4,0.5 \mathrm{M} \mathrm{NaCl}, 1 \mathrm{mM} \mathrm{MgCl} 2,1$ $\mathrm{mM} \mathrm{MnCl}, 1 \mathrm{mM} \mathrm{CaCl}{ }_{2}$, filtered successively on a Whatman GF/B $1.0 \mu \mathrm{m}$ and a Millex-HV Millipore 0.45 $\mu \mathrm{m}$ filters and desalted on a column of Sephadex G25 (PD 10, Pharmacia). Hayman et al. [13] have shown that this method preserves the functional properties (binding capacity, immunogenic, enzymatic) of the extracted glycoproteins.

\subsubsection{Protein concentration}

Protein concentration was estimated according to the method of Bradford [4], based on a bovine serum albu- min standard dilution curve (concentration ranges $0.01-0.1 \mathrm{mg} \mathrm{mL}^{-1}$ ). The presence of protein compounds was also determined by measuring the absorbency at 280 nm.

\subsubsection{Purification of the mycelial extracts (figure 1) in order to preserve functional properties}

\subsubsection{Affinity on concanavalin A}

Concanavalin A (Con A) binds molecules containing mannose-rich $\mathrm{N}$ glycans. The binding sugar requires a structure containing the C-3, C-4 and C-5 hydroxyl groups to react with Con A.

The lithium chloride solubilised extract was applied to a Con A Sepharose (Pharmacia) column (automated Economo System BIO-RAD, $00.7 \mathrm{~cm}, \mathrm{~L} 10 \mathrm{~cm}$ ) equilibrated with a solution containing $20 \mathrm{mM}$ Tris $\mathrm{HCl}, \mathrm{pH}$ $7.4,0.5 \mathrm{M} \mathrm{NaCl}, 1 \mathrm{mM} \mathrm{MgCl}, 1 \mathrm{mM} \mathrm{MnCl}, 1 \mathrm{mM}$

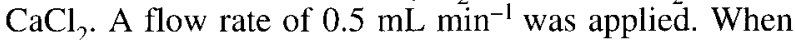
absorbency at $280 \mathrm{~nm}$ increased slightly owing to the presence, in the eluate, of the first unbound proteins, the flow was stopped and the sample left in contact with Con A for $30 \mathrm{~min}$. Fractions of $4 \mathrm{~mL}$ absorbing at $280 \mathrm{~nm}$ were automatically collected. A protein fraction unbound to Con A was first collected. Con A bound fractions were eluted at a flow rate of $0.1 \mathrm{~mL} \mathrm{~min}^{-1}$ by competition using sequentially a gradient of $\alpha \mathrm{D}$-methylglu-

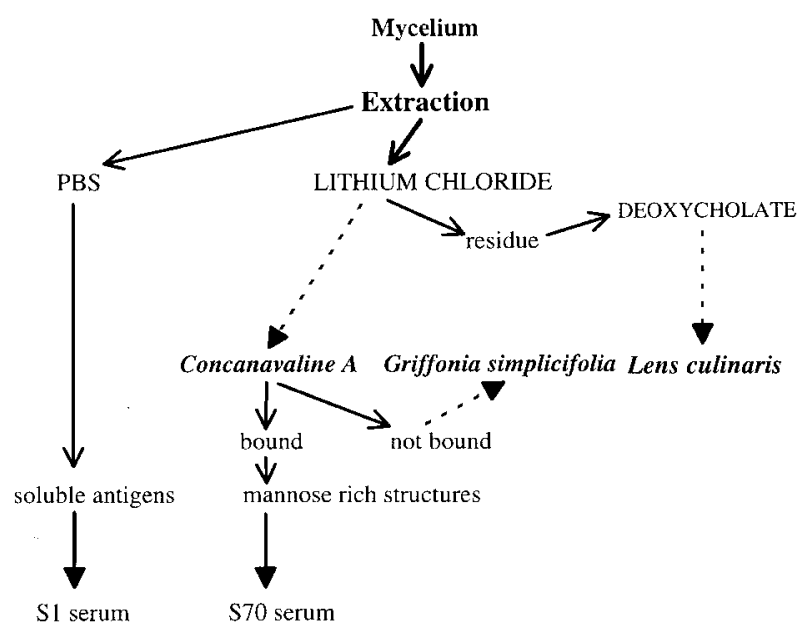

Figure 1. Extraction and characterisation of the mycelial proteins of the fungal pathogens of the pea 'Ascochyta complex'. 
copyranoside $(0-0.1 \mathrm{M})$, followed by a gradient of $\alpha \mathrm{D}$ methylmannopyranoside $(0-0.5 \mathrm{M})$ at a flow rate of $0.2 \mathrm{~mL} \mathrm{~min} \mathrm{~m}^{-1}$. Three fractions were obtained: 1) an unbound fraction, without specificity to Con $\mathrm{A}$; 2) a bound fraction, eluted with $\alpha \mathrm{D}$-methylglucopyranoside; 3) a bound fraction, eluted with $\alpha$ D-methymannopyranoside. Each fraction was desalted in a column of Sephadex G25 (PD 10, Pharmacia).

\subsubsection{Affinity on Griffonia simplicifolia lectin}

Griffonia simplicifolia GS-I lectin presents a major affinity for $\alpha$ D-galactosyl residues and a secondary affinity for $\mathrm{N}$ acetyl- $\alpha \mathrm{D}$ galactosaminyl terminal residues.

A sample ( $3 \mathrm{~mL})$ of the lithium chloride extract fraction unbound to Con A was put in contact with a bed volume of the lectin Griffonia simplicifolia (GS-I, Sigma) coupled to $\mathrm{CNBr}$-activated Sepharose 4B (Pharmacia) in a beaker and left standing for $30 \mathrm{~min}$. The mixture was then poured onto a column (BIO-RAD: $\phi 0.7 \mathrm{~cm}, \mathrm{~L}$ $10 \mathrm{~cm}$, automated Economo System) equilibrated with $0.15 \mathrm{M}$ of $\mathrm{NaCl}$ and $0.01 \mathrm{M} \mathrm{Na}_{2} \mathrm{HPO}_{4} 12 \mathrm{H}_{2} \mathrm{O}$ at a flow rate of $0.1 \mathrm{~mL} \mathrm{~min}^{-1}$. The column was washed with at least ten volumes of starting buffer to eliminate unspecific bound proteins.

The bound molecules were successively eluted with $0.1 \mathrm{M}$ of $\mathrm{N}$-acetyl-D-galactosamine, $0.5 \mathrm{M}$ of D-galactose and $0.1 \mathrm{M}$ de $\mathrm{N}$-acetyl-D-glucosamine. The effluent absorbing at $280 \mathrm{~nm}$ was collected, purified on a column of Sephadex G25 (PD 10, Pharmacia), freeze-dried and maintained at $-20{ }^{\circ} \mathrm{C}$.

\subsubsection{Affinity on lectin from Lens culinaris}

\section{Sepharose $4 B$}

Lentil lectin Sepharose 4B (Lens culinaris) presents an affinity similar to Con A. Sodium deoxycholate at a concentration of $1 \%$ is used to disperse membranes because the soluble glycoprotein components still retain their ability to bind to lentil lectin [13].

The $1 \%$ sodium deoxycholate extracts were applied to a column (BIO-RAD: $\phi 0.7 \mathrm{~cm}, \mathrm{~L} 10 \mathrm{~cm}$ ) containing lentil lectin Sepharose 4B equilibrated with a $1 \%(\mathrm{w} / \mathrm{v})$ sodium deoxycholate solution in $10 \mathrm{mM}$ Tris $\mathrm{HCl}, \mathrm{pH}$ $8.2,0.9 \mathrm{M} \mathrm{NaCl}$ at a flow rate of $0.5 \mathrm{~mL} \mathrm{~min}^{-1}$. When the absorbency of the eluate at $280 \mathrm{~nm}$ started to increase, the flow was stopped and the sample left in contact with the lentil lectin for $30 \mathrm{~min}$.

The flow was re-established and the column was washed with at least ten bed volumes of starting buffer to elute unbound proteins, followed by $2 \%(w / v)$ of $\alpha$-D- methyl-glucopyranoside and $2 \%$ (w/v) $\alpha$-D-methylmannopyranoside in $1 \%$ sodium deoxycholate.

\subsubsection{Serology}

\subsubsection{Detection of sugars in glycoconjugates by an enzyme immunoassay (Boehringer, Mannheim)}

The different fractions absorbing at $280 \mathrm{~nm}$ were blotted onto nitrocellulose. Dot blots of the different fractions are studied with the DIG Glycan Detection Kit (Boehringer, Mannheim). Hydroxyl groups in sugars of glycoconjugates are oxidised to aldehyde groups by periodate treatment. Digoxigenin is then attached to these aldehydes via a hydrazide group. Digoxigenin-labelled conjugates are detected by an enzyme immunoassay (digoxigenin-specific antibody conjugated with alkaline phosphatase).

Glycans were detected in all the extracts before affinity chromatography.

\subsubsection{ELISA procedure}

The antigen-coated plate ELISA (ACP-ELISA) was conducted. Polystyrene plates 'Nunc Immunoplate Maxisorp', Nunc A/S, Roskilde, Denmark) were used. All test volumes were $100 \mu \mathrm{L}$ per well and three replicates were used for each sample. The wells were washed three times with PBS-T (PBS, containing $0.1 \% \mathrm{v} / \mathrm{v}$ Tween 20, $0.02 \% \mathrm{NaN}_{3}$ ) between each incubation step. Positive (homologous antigen) and negative (buffer) controls were included in each plate.

Microtitre plates were coated with antigens (mycelium extracts) that were adjusted to 0.5 or $1 \mu \mathrm{g}$ of proteins $\mathrm{mL}^{-1}$ in carbonate buffer (coating), and incubated for $2 \mathrm{~h}$ at $37^{\circ} \mathrm{C}$ and overnight at $4{ }^{\circ} \mathrm{C}$.

Antiserum diluted in PBS-T containing $0.2 \%(\mathrm{w} / \mathrm{v})$ BSA (Bovine serum albumin, Serva, Heidelberg, Germany), was added and incubated for $2 \mathrm{~h}$ at $37^{\circ} \mathrm{C}$.

The conjugate, alkaline phosphatase-goat anti-rabbit IgG (Sigma Chemical Co, St Louis, USA) was diluted 9000 fold in the buffer described above, and incubated for $1 \mathrm{~h} 30 \mathrm{~min}$ at $37^{\circ} \mathrm{C}$.

Alkaline phosphatase substrate (P-nitrophenylphosphate substrate (Sigma)) was added at $1 \mathrm{mg} \mathrm{mL}^{-1}$ of diethanolamine buffer $(\mathrm{pH} \mathrm{9.8)} \mathrm{and} \mathrm{the} \mathrm{reaction} \mathrm{mixture}$ incubated at room temperature.

Measurements of the absorbency at $405 \mathrm{~nm}$ were taken at 10 min interval for $\mathbf{1} \mathbf{h}$ with a 'Emax' (Molecular 
Devices, Palo Alto, CA, USA) connected to a computer. Slopes of $\mathrm{A}_{405}$ readings were computed and reported as $\mathrm{d}\left(\mathrm{A}_{405}\right) / \mathrm{d} t$. Slopes show the evolution of absorbency with time, thus allowing a better comparison of wells with different evolution rates, and of plates read at different times.

\subsubsection{Antisera production}

Two male, 13-week-old, New Zealand white rabbits were bled and their pre-immune serum collected as a control. The animals were then immunised by intramuscular injections of $500 \mu \mathrm{L}$ of mycelial extracts of Mycosphaerella pinodes emulsified with an equal volume of Freund's complete adjuvant (at a final concentration of $1 \mathrm{mg} \mathrm{mL}-1$ ). Booster injections of the same extracts with Freund's incomplete adjuvant were made 4 and 6 weeks later and the rabbits bled 10-14 days after each boost. After incubation at $37^{\circ} \mathrm{C}$ for $1-2 \mathrm{~h}$ and at $4{ }^{\circ} \mathrm{C}$ overnight, antisera were collected, centrifuged at $800 \mathrm{~g}$ for $10 \mathrm{~min}$ and stored as $1 \mathrm{~mL}$ aliquots at $-20^{\circ} \mathrm{C}$. Two antisera, collected after the last boost, had the highest titre and were selected for all subsequent experiments:

\section{S1, anti-mycelial soluble extract [10];}

S70, produced with the lithium chloride soluble fraction bound to Con $\mathrm{A}$ and eluted with $\alpha$-D-methylmannopyranoside.

\section{RESULTS}

\subsection{Presence of glycans in the separated fractions}

The presence of glycan structures was detected in all extracts before affinity chromatography. Moreover, positive responses were obtained for the following fractions absorbing at $280 \mathrm{~nm}$ (figure 2): bound to Con $A$ and a) eluted with $\alpha-D$ glucoside, b) eluted with $\alpha$-D-mannoside, unbound to Con A, bound to Griffonia simplicifolia and eluted with Nacetyl-D-galactosamine and soluble in deoxycholate (weak response). The response was similar for the three species of fungi.

\subsection{Characterisation of the glycoprotein structures}

\subsubsection{Concanavalin A}

Three groups of substances absorbing at $280 \mathrm{~nm}$ were obtained. The first, and the most important, is

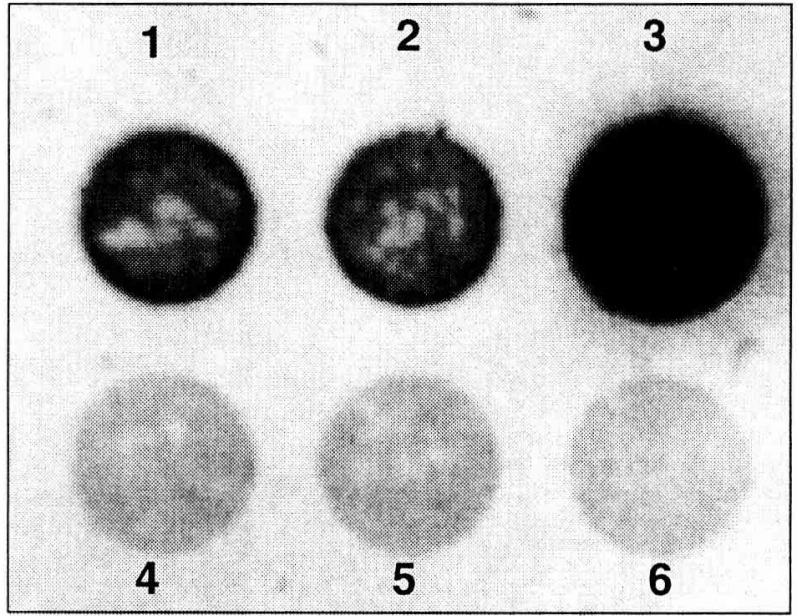

Figure 2. Detection of glycans (enzyme immunoassay, DIG Glycan Kit, Boehringer, Mannheim) in the fractions obtained from $M y c o s p h a e r e l l a$ pinodes mycelial extract and blotted onto nitrocellulose: 1, soluble on lithium chloride; 2, eluted from concanavalin A with $\alpha$-D-glucoside; 3 , eluted from concanavalin A with $\alpha$-D-mannoside; 4 , unbound to concanavalin A; 5, eluted from Griffonia simplicifolia with N-acetyl-Dgalactosamine; 6 , soluble in deoxycholate.

composed of the protein conjugates not bound to Con A (without mannose-rich $\mathrm{N}$-glycans). The second is obtained by elution of the glycoproteins bound to Con $\mathrm{A}$ with $\alpha$-D-glucopyranoside. The last group is obtained by elution of the bound molecules with $\alpha$-D-methylmannopyranoside. Similar absorption profiles were obtained for the three species of fungi.

\subsubsection{Griffonia simplicifolia}

Two types of substances absorbing at $280 \mathrm{~nm}$ were obtained: unbound protein compounds and glycoproteins bound to Griffonia simplicifolia and eluted with $\mathrm{N}$-acetyl-D-galactosamine solution.

Affinity chromatography with Griffonia simplicifolia produced similar absorption profiles at $280 \mathrm{~nm}$ for the three species of fungi.

\subsubsection{Lens culinaris}

Competitive elution from Lens culinaris lectin of the sodium deoxycholate extract did not produce 
any substances with an absorbency at $280 \mathrm{~nm}$. The sodium deoxycholate extract that was put in the column showed a positive but weak response using the DIG Glycan detection kit.

The unbound eluate, without specificity to Lens culinaris lectin, presented a weak absorption peak at $280 \mathrm{~nm}$ and a negative response to the DIG Glycan Kit.

\subsection{Comparison between the three fungal pathogens referred as the 'Ascochyta complex'}

This work revealed the presence of glycoprotein structures that could bind specifically to the lectins from concanavalin A and Griffonia simplicifolia in the mycelial extracts of the three species. A glycoprotein fraction extracted with lithium chloride contained mannose rich $\mathrm{N}$-glyconjugate structures (bound to Con $\mathrm{A}$, eluted with $\alpha$-D-mannoside). Another fraction absorbing at $280 \mathrm{~nm}$ that specifically bound to Con $A$ contains glucose-rich glycoprotein structures (eluted by $\alpha$-D-glucoside). The fraction containing glycans but without affinity to Con $A$ was characterised by the lectin from Griffonia simplicifolia. A portion bound to this lectin and was eluted by N-actyl-D-galactosamine, thus revealing the presence of galactosamine terminal residues. As competitive elution from Lens culinaris of the deoxycholate extract did not desorbed substances absorbing at $280 \mathrm{~nm}$, the glycans detected in the deoxycholate fraction are not glycoproteins, but glycolipids or polysaccharides.

\subsection{ELISA response of the fractions separated by chromatography}

\subsubsection{To the antiserum S1 raised to the soluble mycelial extract of Mycosphaerella pinodes (figure 3)}

ACP-ELISA responses to $\mathrm{S} 1$ antiserum for the three fungi (A. pisi, $M$. pinodes and P. m. var. pin-

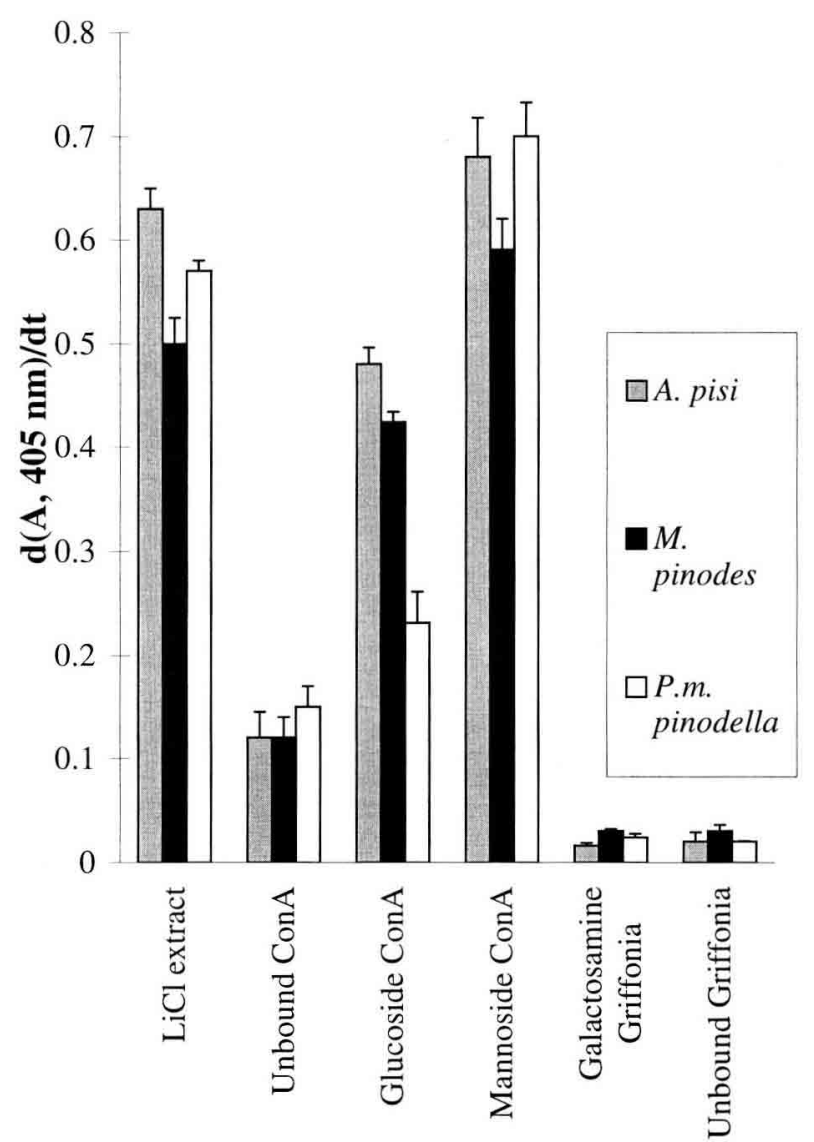

Figure 3. ACP-ELISA response of the different fractions of $A$. pisi, M. pinodes and P.m. var. pinodella isolated by affinity chromatography to $\mathrm{SI}$ serum raised against Mycosphaerella pinodes mycelial extract. Antigens were extracted from the mycelium by lithium chloride ( $\mathrm{LiCl}$ ), and separated on concanavalin A (Con A) and Griffonia simplicifolia (Griffonia) lectins by affinity chromatography. Bars indicate standard errors for the means of three replicates.

odella), were similar for the fractions presenting the same lectin specificity.

The response of the different fractions to the $\mathrm{S} 1$ serum is presented in figure 3. The strongest reaction was obtained with the fraction bound to concanavalin $\mathrm{A}$ and eluted with $\alpha$-D-mannoside $(\mathrm{N}$ glycosylated and mannose rich), followed by the fraction bound to concanavalin $\mathrm{A}$ and eluted with $\alpha$-D-glucoside. The reaction of the fraction absorb- 
ing at $280 \mathrm{~nm}$ without affinity (not bound) to concanavalin $A$ was weak.

The reaction obtained with the whole lithium chloride extract before purification was weaker then with the fraction containing the mannose-rich structures. The two fractions separated with Griffonia simplicifolia lectin, unbound and eluted with Nacetyl-D-galactosamine, gave a similar response to the negative control.

\subsubsection{To the antiserum $S 70$ raised to the mycelial fraction of Mycosphaerella pinodes eluted with $\alpha$-D-mannoside (figure 4)}

A very high ACP-ELISA response (figure 4) to the anti-sera S70 was obtained for the mycelial glycoproteins containing mannose-rich structures (extracted with lithium chloride, bound to Con A and eluted with $\alpha$-D-mannoside), not only extracted from Mycosphaerella pinodes (homologous antigen), but also for the ones extracted from Ascochyta pisi and Phoma medicaginis var. pinodella.

The results obtained for the three species were similar (figure 4). The serum specificity was not improved.

\section{DISCUSSION}

Our work revealed that similar structures with affinity to the lectins of concanavalin A and Griffonia simplicifolia were present in the mycelial extracts of the three fungal pathogens referred as the 'Ascochyta pea complex'. Gandon [11] isolated from the culture filtrate and the mycelial wall of a carnation fungal pathogen (Fusarium oxysporum) a polysaccharide fraction eliciting phytoalexin synthesis in carnation and containing mannose, glucose and galactose. Matsubara and Kuroda [20] found mannosyl and glucosyl residues in a glycoprotein of the O-glycoside type secreted from conidia of Mycosphaerella pinodes during germination. Our work detected the presence of mannose-rich structures of the $\mathrm{N}$-glycoside type (presenting affinity to Con A) in the mycelial lithium chloride extract of

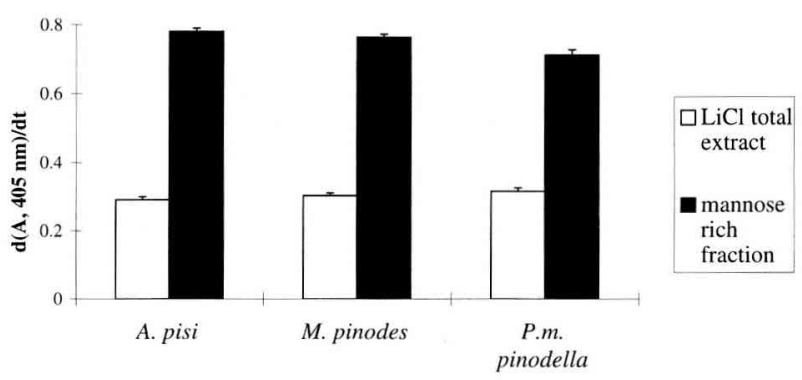

Figure 4. ACP-ELISA response of lithium chloride extracts and mannose-rich structures from the mycelium of $A$. pisi, $M$. pinodes and P.m. var. pinodella to $\mathrm{S} 70$ serum raised against the $M$. pinodes glycoproteins. Bars represents standard errors for the means of three replicates.

the three fungal pathogens referred to as the 'Ascochyta complex'. Ding et al. [8] showed that the adhesion of Phytophthora megasperma to the host (soybean) is due to glycoproteins presenting affinity to Con $\mathrm{A}$ and found that D-mannose could inhibit this adhesion. Peberty [21] suggested that $\mathrm{O}$ glycosylation of a protein is essential for secretion and $\mathrm{N}$-glycosylation is important for stability (protection against proteolyse, $\mathrm{pH}$ variations).

The affinity properties of the glycoconjugates extracted from the mycelium of the three species revealed not only the presence of mannose, glucose and galactose, but also of binding structures containing these sugars. The serological properties of those glycoconjugated structures extracted with lithium chloride coincide with the affinity chromatography properties. Similar glycan structure of the three fungi (thus presenting the same affinity) could not be differentiated serologically with the S1 serum.

The three fractions presenting different affinities isolated from the mycelium of all species (eluted from Con A with $\alpha$-D-glucoside and $\alpha$-D-mannoside, or eluted from Griffonia simplicifolia), showed different immunoenzyme responses (ELISA) to the S1 serum.

This study proved that, among the mycelial glycoproteins, the fraction recognised the most strongly by the $S 1$ serum was the fraction containing the mannose-rich glycan structures. This result lead to the production of the $\mathrm{S} 70$ serum raised against this 
fraction, but the specificity was not improved. The mannose-rich glycoproteins are the most antigenic but could not lead to the production of a serum distinguishing the three species.

In conclusion, the results proved the presence in the three fungi of the pea 'Ascochyta complex' of mannose-rich $\mathrm{N}$-glycans structures that were strongly antigenic and non-specific.

It would be interesting to study the role of these mycelium structures in the plant-pathogen interaction, in order to provide a better understanding and control of these pathogens.

Acknowledgements: The authors thank Dr M. Laurière (Inra-INA PG, Centre de Biotechnologies Agro-Industrielles, 78850 Thiverval-Grignon) for helpful advice concerning the manuscript and Mrs G. Tuncer (Plant Protection Research Institute, Ankara, Turkey) for helpful discussions and technical assistance.

\section{REFERENCES}

[1] Barak R., Chet I., Lectin of Sclerotium rolfsii: its purification and possible function in fungal-fungal interaction, J. Appl. Bacteriol. 69 (1990) 101-112.

[2] Barak R., Elad Y., Mierlman D., Chet I., Lectins: a possible basis for specific recognition in the interaction of Trichoderma and Sclerotium rolfsii, Phytopathol. 77 (1985) 458-462.

[3] Bowen J.K., Peart J., Lewis B.G., Cooper C., Matthews P., Development of monoclonal antibodies against the fungi of the Ascochyta complex, Plant Pathol. 45 (1996) 393-406.

[4] Bradford M., A rapid and sensitive method for the quantification of microgram quantities of protein utilizing the principle of protein-dye binding, Anal. Biochem. 72 (1976) 248-254.

[5] Bröker M., Harthus H.P., Barnes R.M.R., A murine monoclonal antibody directed against a yeast cell wall glycoprotein antigen of the yeast genus Saccharomyces, FEMS Microbiol. Lett. 118 (1994) 297-304.

[6] Chrispeels J., Raikhel N.V., Lectins, lectin genes, and their role in plant defense, Plant Cell 3 (1991) 1-9.

[7] Dewey F.M., MacDonald M.M., Phillips S.I., Development of monoclonal antibody ELISA, DOT BLOT, and DIP STICK immunoassays for Humicola lanuginosa in rice, J. Gen. Microbiol. 135 (1989) 361-374.

[8] Ding H., Balsiger S., Guggenbühl C., Hohl H.R., A putative IgG-binding $65 \mathrm{Kda}$ adhesin involved in adhesion and infection of soybeans by Phytophtora megasperma f. sp. glycinea. Physiol. Mol. Plant Pathol. 44 (1994) 363-378.

[9] Faris-Mokaiesh S., Boccara M., Denis J.B., Derrien A., Spire D., Differentiation of the 'Ascochyta complex' fungi of pea by biochemical and molecular markers, Curr. Genet. 29 (1996) 182-190.

[10] Faris-Mokaiesh S., Corbière R., Lyons N., Spire D., Evaluation of an enzyme-linked immunosorbent assay for detection of Mycosphaerella pinodes in pea seeds, Ann. Applied Biol. 127 (1995) 441-455.

[11] Gandon C., Bruneteau M., Ponchet M., Ricci P., Étude biochimique des polysaccharides et glycoconjugues isolés de Phytophtora parasitica Dastur et Fusarium oxysporum f. sp. Dianthi inducteurs de la synthèse de phytoalexines chez l'œillet., IV ${ }^{\mathrm{e}}$ Congrès Soc Française Phytopathol, Parc Phœnix, Nice 19-22 November, 1996.

[12] Gessler C., Kuc J., Induction of resistance to Fusarium wilt in cucumber by root and foliar pathogens, Phytopathol. 72 (1982) 1439-1441.

[13] Hayman M.J., Skehel J.J., Crumpton M.J., Purification of virus glycoproteins by affinity chromatography using Lens culinaris phytohemaglutunin. FEBS Lett. 29 (1973) 185-188.

[14] Heelan, B.T., Allan S., Barnes R.M.R., Identification of a $200-\mathrm{kDa}$ glycoprotein antigen of Saccharomyces cerevisae, Immunol. Lett. 28 (1991) 181-186.

[15] Hervas A., Trapero-Casas J.L., Jiménez-Diaz R.M.,. Induced resistance against Fusarium Wilt of chickpea by nonpathogenic races of Fusarium oxysporum f. sp. ciceris and nonpathogenic isolates of $F$. oxysporum, Plant Dis. 79 (1995) 1110-1116.

[16] Hills G.J., Phillips J.M., Gay M.R., Roberts K., Self-assembly of a Plant Cell Wall in vitro, J. Mol. Biol. 96 (1975) 431-441.

[17] Laurière M., Laurière C., Chispeels M.J., Johnson K.D., Sturm A., Characterization of a xylosespecific antiserum that reacts with the complex asparagine-linked glycans of extracellular and vacuolar glycoproteins, Plant Physiol. 90 (1989) 1182-1188.

[18] Macdonald M.M., Dunstan R.H., Dewey F.M., Detection of low-Mr glycoproteins in surface washes of some fungal cultures by gel-filtration HPLC and by 
monoclonal antibodies, J. Gen. Microbiol. 135 (1989) 375-383.

[19] Manocha M.S., Sahai A.S., Cell surface characterisation of five haustorial mycoparasites with lectin probes, Mycologia 83 (1991) 643-649.

[20] Matsubara M., Kuroda H., The structure and physiological activity of a glycoprotein secreted from conidia of Mycosphaerella pinodes, Chem. Pharm. Bull. 35 (1987) 249-255.

[21] Peberty J.F., Protein secretion in filamentous fungi - trying to understand a highly productive black box, Tib. Tech. 12 (1994) 50-57.

[22] Sbrana C., Avio L., Giovannetti M., The occurrence of calcofluor and lectin binding polysaccarides in the outer wall of arbuscular mycorrhizal fungal spores, Mycol. Res. 99 (10) (1995) 1249-1252.

[23] Teepe H., Botge J.A., Wostemeyer J., Isolation and electrophoretic analysis of surface proteins of the zygomycete Absidia glauca, FEBS Lett. 234 (1988) 100-106.
[24] Tivoli B., Lemarchand E., Mace F., Pois protéagineux. Les maladies aériennes fongiques et bactériennes. Observatoire 1991, Perspect. Agric. 170 (1992) $52-58$.

[25] Voigt J., Extraction by lithium chloride of hydroxyproline-rich glycoproteins from intact cells of Chlamydomonas reinhardii, Planta 164, (1985) 379-389

[26] Wade M., Albersheim P., Race-specific molecules that protect soybeans from Phytophthora megasperma var. sojae, Proc. Natl. Acad. Sci. 76 (1979) $4433-4437$.

[27] Wycoff K.L., Ayers A.R., Monoclonal antibodies to glycoprotein antigens of a fungal plant pathogen, Phytophthora megasperma f. sp. glycinea, recognise specific carbohydrate epitopes, Physiol. Mol. Plant Pathol. 37 (1990) 55-79.

[28] Wycoff K.L., Jellison J., Ayers A.R., Monoclonal antibodies to glycoprotein antigens of a fungal plant pathogen, Phytophthora megasperma f. sp. glycinea, Plant Physiol. 85 (1987) 508-515. 